\title{
PEMANFAATAN LIMBAH PLASTIK MENJADI BAHAN BAKAR MINYAK Rafidah $^{1}$ dan Ahmad Ridho Ismail ${ }^{2}$ \\ ${ }^{1.2}$ Poltekkes Kemenkes Makassar ahmadridhoismail77@gmail.com
}

\begin{abstract}
Indonesia was the second-ranked in the world in terms of plastics waste disposal into the sea, with the amount of 187.2 Milion tons. More than million of plastics bags were used in a minute, and $50 \%$ of them only this disposable. The purpose of this research was to know the ability of the plastics wast procession tool using the pyrolysis method in producing fuel. It was quasiexperiment research. Plastics PET was the sample of research. They were part of the population that became the research object. To know the amount of fuel produced using the pyrolysis method in 20, 40, to 60 minutes. To know the waste reduction after plastics waste processed into fuel. The pyrolysis method used in this research is able to produce fuel oil (BBM) that is as much as $36,67 \mathrm{ml}$ with boiling point $100 \cong \mathrm{C}$ at minute 20 , as many as $114,80 \mathrm{ml}$ at minute 40 with boiling point $270 \cong \mathrm{C}$, and at minute 60 as much $201.67 \mathrm{ml}$ with boiling point $270^{\circ} \mathrm{C}$. With a decrease of $0.7 \mathrm{~kg}$ plastic solid waste or $70 \%$ of each mass of $1 \mathrm{~kg}$ of PET plastic. The calorific value of oil produced after going through the pyrolysis process is 11761,5049 calories/gr. This research concluded that the Purolator was able to produce fuel. Therefore it was required to conduct further research about the influence of temperature in the process of plastics. the type of fraction in the fuel, and if it is developed on a production scale, the research required to conducted using the continuous reactor, so that the activation process could be conducted continuously.
\end{abstract}

Key word: plastics waste, fuel

\section{ABSTRAK}

Indonesia berada di peringkat kedua dunia penghasil sampah plastik ke laut yang mencapai sebesar 187,2 juta ton. Lebih dari satu juta kanotng plastik digunakan setiap menitnya, dan $50 \%$ dari kantong plastik tersebut dipakai hanya sekali lalu langsung dibuang. Tujuan penelitian ini adalah untuk mengetahui kemampuan alat pengolahan limbah plastik dengan menggunakan Metode Pirolisis menjadi bahan bakar minyak. Jenis penelitian ini merupakan quasi eksperimen. Mengetahui banyaknya Bahan Bakar Minyak (BBM) yang dihasilkan dengan menggunakan metode pirolisis dalam waktu 20,40 dan 60 menit, dan untuk mengetahui banyaknya penurunan sampah dengan pemanfaatan limbah plastik menjadi Bahan Bakar Minyak (BBM). Metode pirolisis yang digunakan dalam penelitian ini mampu menghasilkan bahan bakar minyak (BBM) yaitu sebanyak 36,67 ml pada menit ke 20 , sebanyak $114,80 \mathrm{ml}$ pada menit ke 40, dan pada menit ke 60 sebanyak 201,67 ml, dengan penurunan padatan sampah plastik $0,7 \mathrm{~kg}$ atau $70 \%$ dari masing-masing massa $1 \mathrm{~kg}$ plastik PET. Dengan nilai kalor minyak yang dihasilkan setelah melalui proses pirolisis yaitu 11761,5049 kalori/gr. Kesimpulan dari penelitian ini adalah alat pirolisator mampu menghasilkan bahan bakar minyak (BBM). Untuk itu, diharapkan peneliti selanjutnya perlu melakukan penelitian lebih lanjut mengenai pengaruh suhu terhadap proses pirolisis plastik, jenis fraksi pada minyak hasil pirolisis, dan apabila dikembangkan dalam skala produksi maka perlu diteliti lagi menggunakan reaktor jenis kontinyu, sehingga proses pengolahan bisa berlangsung terus menerus.

Kata kunci :Limbah Plastik, Bahan Bakar Minyak

\section{PENDAHULUAN}

Sampah plastik merupakan sampah yang paling banyak dibuang oleh manusia karena banyak orang yang menggunakan plastik untuk keperluannya sehari-hari entah itu perorangan, toko, maupun perusahaan besar.Pembuangan sampah-sampah plastik ke dalam air dan tanah juga marak terjadi, hal tersebut semakin memicu kerusakan alam Karena sampah plastik terbuat dari bahan anorganik. Bahan-bahan an-organik tersebut sangat sulit dan tidak mungkin diuraikan oleh bakteri pengurai. Apabila ditimbun di dalam tanah untuk menguraikannya butuh waktu berjutajuta tahun. Dan apabila dibakar hanya akan menjadi gumpalan dan butuh waktu lama untuk menguraikannya. Jika sampah-sampah plastik itu tertimbun di dalam tanah hingga menumpuk, maka akan mengakibatkan dampak berupa pemanasan global bagi kehidupan manusia itu sendiri. Dan jika sampah-sampah plastik ini terbawa ke sungai atau ke laut, maka akan mengakibatkan kerusakan terhadap ekosistem di daerah tersebut.
Menurut Kementerian Lingkungan Hidup dan Kehutanan (KLHK) tahun 2008 menilai persoalan sampah sudah meresahkan. Indonesia bahkan masuk dalam peringkat kedua di dunia sebagai penghasil sampah plastik ke Laut setelah Tiongkok. Hal itu berkaitan dengan data dari Kementerian Lingkungan Hidup dan Kehutanan (KLHK) yang menyebutkan bahwa plastik hasil dari 100 toko atau anggota Asosiasii Pengusaha.( KLHK 2008 dalam Wega 2017 ).

Berdasarkan data Jambeck (2015), Indonesia berada di peringkat kedua dunia penghasil sampah plastik ke laut yang mencapai sebesar 187,2 juta ton setelah Cina yang mencapai 262,9 juta ton. Berada di urutan ketiga adalah Filipina yang menghasilkan sampah plastik ke laut mencapai 83,4 juta ton, diikuti Vietnam yang mencapai 55,9 juta ton, dan Sri Lanka yang mencapai 14,6 juta ton pertahun. Setiap tahun produksi plastik menghasilkan sekitar delapan persen hasil produksi minyak dunia atau sekitar 12 juta barel minyak atau setara 14 juta pohon. Lebih dari satu juta kantong plastik digunakan setiap 
Jurnal Sulolipu : Media Komunikasi Sivitas Akademika dan Masyarakat

Vol. 18 No 22018

e-issn : 2622-6960, p-issn : 0854-624X

menitnya, dan 50 persen dari kantong plastik tersebut dipakai hanya sekali lalu langsung dibuang. Dari angka tersebut, hanya lima persen yang benar-benar di daur ulang. (Wega, 2017).

Pertumbuhan penduduk diakui atau tidak, telah menimbulkan akibat bertambahnya pola konsumsi masyarakat yang akhirnya menyebabkan bertambahnya volume bukan hanya pada jumlah, tetapi juga pada jenis sampah yang semakin beragam. Kondisi ini diperparah dengan pola hidup masyarakat yang instan dan paradigma yang menganggap sampah sebagai sesuatu yang harus dibuang dan disingkirkan.(Ronny, 2014). Berdasarkan asumsi Kementerian Lingkungan Hidup (KLH) setiap hari penduduk Indonesia menghasilkan $0,8 \mathrm{~kg}$ sampah per orang atau secara total sebanyak 189 ribu ton sampah/hari. Dari jumlah tersebut $15 \%$ berupa sampah plastik atau sejumlah 28,4 ribu ton sampah plastik/hari (Sumarni,2008). Berdasarkan Data yang diperoleh dari Dinas Pertanaman dan Kebersihan Kota Makassar (2014) terkait dengan jumlah total timbulan adalah $4.494,86 / \mathrm{m}^{3}$, dan plastik jumlah timbulan $425,66 / \mathrm{m}^{3}$ dalam setiap Bulan.

Minyak mentah adalah bahan utama dari plastik dan sebagian besar bahan kimia. Dari total 100 juta ton plastik diproduksi setiap tahun di seluruh dunia, 25 juta ton dibuang. Dengan membuang jumlah berat seperti limbah plastik, banyak membuang energi dalam bentuk minyak mentah yang digunakan untuk membuat plastik. Energi yang terbuang dapat dipulihkan kembali menggunakan proses Pirolisis. Proses ini menghemat sumber energi konvensional kami yaitu minyak mentah Satu kg limbah plastik menghasilkan 1 liter bahan dasar minyak atau minyak mentah . ketika diolah jadi premium atau solar.

Menurut Mohana jeya, dkk (2012) Limbah plastik dianggap sebagai berpotensi sumber ekonomi bahan kimia dan energi. Banyak darii kita telah menemukan berbagai produk yang menggunakan bahan plastik hari ini. Sebagai hasil dari meningkatnya tingkat konsumsi swasta bahanbahan plastik dalam jumlah besar limbah yang dibuang ke lingkungan. catalytic cracking ( Proses retak ) adalah proses yang mengubah limbah plastik menjadi produk hidrokarbon cair berharga yang dapat dimanfaatkan sebagai sumber energi untuk berbagai keperluan seperti mesin diesel, generator, kendaraan, dll gas produk sampingan yang diperoleh dalam proses dapat digunakan untuk domestik gunakan dengan. mengisi dalam silinder dan juga untuk menjalankan turbin gas.
Dengan demikian proses retak dapat dianggap sebagai sumber energi non-konvensional lain.

Menurut penelitian Kadir (2012) "Kajian

Pemanfaatan Sampah Plastik Sebagai Sumber Bahan Bakar Cair" didapatkan hasil bahan baku plastic jenis kantong kresek ( PP) dengan massa 500 gram yaitu $484 \mathrm{ml}$ bahan bakar, bahan botol oli ( HDPE ) massa 500 gram yaitu $403 \mathrm{ml}$ bahan bakar. Menurut penelitian Aprian Ramadhan P. dan Munawar Ali "pengolahan sampah plastik menjadi minyak menggunakan proses pirolisis " di dapatkan hasil dengan bahan baku plastic ( HDPE ) dengan massa 500 gram terjadi pada suhu $400^{\circ} \mathrm{C}$ dan waktu operasi 60 menit dengan jumlah produk sebesar $453 \mathrm{ml}$ bahan bakar. dan bahan baku plastik ( LDPE ) dengan massa 500 gram terjadi pada suhu $400^{\circ} \mathrm{C}$ dan waktu operasi 60 menit dengan jumlah produk sebesar $445 \mathrm{ml}$ bahan bakar. Menurut penelitian Untoro Budi Surono dan Ismanto "Pengolahan Sampah Plastik Jenis PP, PET dan PE Menjadi Bahan Bakar Minyak dan Karakteristiknya " adapun hasil yang di dapatkan jenis plastik ( PP ) $450 \mathrm{ml}$ bahan bakar, jenis plastik ( PET ) tidak menghasilkan bahan bakar dan jenis plastik ( PE ) menghasilkan $350 \mathrm{ml}$ bahan bakar.

\section{BAHAN DAN METODE}

1. Lokasi Penelitian:

Penelitian ini dilakukan di Workshop Politeknik Kesehatan Makassar Jurusan Kesehatan Lingkungan.

2. Desain dan Variabel Penelitian

Jenis penelitian merupakan penelitian eksperimen koasi skala yaitu untuk mengetahui kemampuan alat pengolahan limbah plastik dalam menghasilkan bahan bakar minyak selama 20,40 dan 60 menit dengan 3 kali Replikasi.

Adapun variabel penelitian pada penelitian ini terdiri dari 3 variabel yaitu variabel bebas yang terdiri dari Pirolisis plastik PET selama 20,40 60 menit dan variabel terikat yaitu jumlah BBM yang dihasilkan Sisa padatan sampah, serta variabel pengganggu yang terdiri dari Ukuran Partikel dan Suhu

\section{Populasi dan Sampel}

Populasi dalam penelitian ini adalah Semua limbah plastik yang ada di kota Makassar. Adapun Sampel dalam penelitian ini adalah bagian dari populasi yang dijadikan objek penelitian, yaitu plastik PET. Pengambilan sampel dilakukan dengan menggunakan Metode grab-sample yaitu sampel diambil pada waktu yang sesaat, dan sampel tersebut sudah 
mampu mewakili limbah plastik PET secara keseluruhan, dengan ketentuan $1 \mathrm{~kg} /$ percobaan jadi jumlah sampel dengan 3 kali replikasi adalah $3 \mathrm{~kg}$ limbah plastik PET.

\section{Pengumpulan data}

Sumber data terdiri dari 2 yaitu data primer yang diambil secara langsung oleh peneliti meliputi proses percobaan di labolatorium dan data sekunder yang diperoleh dari sumber lain seperti, penelusuran kepustakaan, berupa buku-buku, refrensi dari internet serta literatur-literatur yang ada hubungannya dengan objek penelitian.

5. Analisa Data (Jika memakai program statistic, tuliskan uji utama apa yang digunakan)

Teknik analisa data dilakukan secara deskriptif untuk mengetahui ada atau tidaknya asap cair (minyak) yang dihasilkan pada proses pirolisis dan digambarkan dalam bentuk tabel atau grafik.

HASIL

1. Hasil Minyak Pirolisis plastik $1 \mathrm{~kg}$ Polypropylene Terephtalate (PET)

Tabel 1

Hasil Minyak Pirolisis plastik 1kg

Polypropylene Terephtalate(PET)

\begin{tabular}{lccc}
\hline No & $\begin{array}{c}\text { Waktu } \\
\text { penyulingan }\end{array}$ & $\begin{array}{c}\text { Hasil } \\
\text { cairan } \\
\text { minyak }\end{array}$ & Suhu \\
& &
\end{tabular}

\begin{tabular}{cccc} 
& (menit) & $(\mathrm{ml})$ & $\left({ }^{\circ} \mathrm{C}\right)$ \\
\hline 1 & 20 & 36,67 & 100 \\
2 & 40 & 114,8 & 270 \\
3 & 60 & 201.67 & 270 \\
\hline
\end{tabular}

2. Sisa padatan Hasil Pirolisis plastik $1 \mathrm{~kg}$ Polypropylene Terephtalate (PET) Tabel 2

Sisa Padatan Hasil Pirolisis plastik $1 \mathrm{~kg}$ Polypropylene Terephtalate

\begin{tabular}{cccc}
$\begin{array}{c}\text { Massa } \\
\text { bahan }\end{array}$ & $\begin{array}{c}\text { Sisa } \\
\text { Padatan }\end{array}$ & $\begin{array}{c}\text { Penurunan } \\
\text { Padatan }\end{array}$ & $\begin{array}{c}\text { Persentase } \\
\text { Penurunan \% }\end{array}$ \\
\cline { 1 - 3 }$(\mathrm{kg})$ & $(\mathrm{kg})$ & $(\mathrm{kg})$ & \\
\hline 1 & 0,3 & 0,7 & $70 \%$ \\
\hline
\end{tabular}

3. Nilai kalor minyak setelah proses pirolis Tabel 3

Uji Fisik Kondensat

Nilai kalor dari minyak plastik yang di hasilkan

\begin{tabular}{cccc}
\hline \multirow{2}{*}{ Kode } & \multicolumn{3}{c}{ Nilai kalor } \\
\cline { 2 - 4 } & $\mathrm{J} / \mathrm{g}$ & Kalori/g & Ket \\
\hline Minyak & 49231,3074 & 11761,5049 & \\
plastik PET & 492 & \\
\hline
\end{tabular}

\section{PEMBAHASAN}

1. Kemampuan Alat Pirolisator

Pirolisis berasal dari kata pyro (fire/api) Lyo (loosening/Pelepasan) untuk dekomposisi termal dari suatu bahan organik. Jadi pirolisis adalah proses konersi dari suatu bahan organik pada suhu tinggi dan terurai menjadi ikatan molekul yang lebih kecil. Pirolisis merupakan suatu bentuk insenerasi yang menguraikan bahan organik secara kimia melalui pemanasan dengan mengalirkan nitrogen sebagai gas inert.

Berdasarkan penelitian yang telah dilakukan, alat pirolisator mampu menghasilkan bahan bakar minyak (BBM) sebanyak 201,67 ml dengan suhu optimum $270^{\circ} \mathrm{C}$ hasil tersebut terdapat pada tabel 1. Dari proses pirolisis, suhu dan waktu adalah faktor yang sangat penting. Peran suhu pada proses pirolisis sangat mempengaruhi waktu dekomposisi termal, seiring waktu reaksi dan suhu dinaikkan, komposisi dari produk pirolisis berkembang menjadi komponen yang lebih stabil. Dekomposisi bahan organik dijabarkan sebagai berikut : $100-200^{\circ} \mathrm{C}$ pengeringan dengan pemanasan (dehidrasi), $250^{\circ} \mathrm{C}$ hilangnya cairan dan carbon dioksida (evolusi hydrogen), $340^{\circ} \mathrm{C}$ putusnya rantai carbon makromolekul, $380^{\circ} \mathrm{C}$ tahap pirolisis, $400^{\circ} \mathrm{C}$ pecahnya rantai $\mathrm{C}-\mathrm{O}$ dan $\mathrm{C}-\mathrm{H}$.

Berbeda dengan penelitian Untoro Budi Surono, (2016) yaitu Pengolahan Sampah Plastik Jenis PP, PET dan PE Menjadi Bahan Bakar Minyak dan Karakteristiknya penelitian ini diketahui bahwa plastik jenis PET (Polypropylene Terephtalate) tidak menghasilkan minyak sama sekali. Material yang keluar dari kondenser semacam serbuk berwarna kekuning-kuningan. Bahkan serbuk ini menempel di sepanjang saluran pipa. Dari hasil ini diketahui bahwa plastik tipe PET tidak potensial untuk diolah menjadi bahan bakar minyak.

Suhu yang digunakan dalam penelitian sebesar $270^{\circ} \mathrm{C}$, dengan menggunakan alat Dial 
thermometer. Setelah suhu operasi tercapai, berat plastik ditimbang dan diketahui jumlah penurunan massa sebagai massa awal. Suhu dijaga konstan dan proses dilanjutkan sampai massa konstan, dilakukan pengamatan.

Adapun hasil luaran dari penelitian ini adalah berupa mesin pengolah limbah sampah plastik menjadi bahan bakar alternatif dengan menggunakan prinsip pirolisis. Adapun system kerja dari mesin ini cukup mudah yaitu sampah plastik dimasukkan kedalam reaktor melalui saluran inlet, setelah itu ditutup dengan menggunakan baut lalu dipanaskan sampai mencapai suhu diatas titik leburnya yaitu $270^{\circ} \mathrm{C}$, kemudian akan keluar uap polimer yang akan melewati pipa pendinginan (kondensor berisi air) dan terjadilah proses kondensasi yang menghasilkan bahan bakar cair. Target luaran yang telah tercapai dalam pembuatan alat ini yaitu alat mampu mengatasi limbah sampah plastik yang sangat sulit terurai agar tidak mencemari lingkungan dan mampu mengolah limbah sampah plastik menjadi bahan bakar cair.

\section{Bahan Bakar Minyak (BBM) yang dihasilkan dengan menggunakan metode pirolisis dalam waktu 20,40 dan 60 menit.}

Dari tabel 1, terlihat bahwa menit 40 ke menit 60 merupakan waktu yg cukup optimum menghasilkan bahan bakar. setelah waktu tersebut alat tidak lagi menghasilkan bahan bakar. Hal ini dipengaruhi pula suhu konstan sehingga membuat waktu optimum menghasilkan bahan bakar adalah di menit ke 40. Pada Percobaan menit ke 20 sampai ke 40 memiliki kenaikan hasil bahan bakar sebanyak $78.13 \mathrm{ml}$ dan menit ke 40 sampai menit ke 60 memiliki kenaikan hasil bahan bakar minyak sebanyak $86,87 \mathrm{ml}$. Tidak terproduksinya lagi bahan bakar pada menit setelah 60 , disebabkan karena waktu kontak antara plastik PET dengan suhu. Waktu kontak tersebut disebut waktu terakhir (waktu optimal) yaitu keadaan pada saat semua zat pada sampel sudah terdekomposisi. Pengaruh waktu terhadap minyak, pada berbagai suhu dapat memberikan ilustrasi mengenai langkah reaksi yang berperan. Seperti halnya pengaruh waktu, kenaikkan suhu pirolis juga menyebabkan bahan yang mudah menguap semakin besar, sehingga plastik yang terdekomposisi menyebabkan adanya kenaikan hasil minyak. Kenaikan itu, terjadi karena gerakan molekulmolekul zat bertambah. Plastik PET memiliki titik didih tertinggi dibandingkan bahan plastik lainya, semakin tinggi suhu yang digunakan maka semakin besar pula fraksi za/bahannya.

Berdasarkan hasil penelitian yang telah dilakukan oleh peneliti, waktu optimal proses pirolisis terjadi pada menit 40 ke 60 , setelah menit ke 60, alat pirolisator sudah tidak mampu lagi menghasilkan minyak, hal ini dikarenakan karbon teroksidasi oleh oksigen menyebabkan karbon terbakar sehingga terbentuk karbondioksida dan abu. Untuk itu pada proses pirolisis penentuan waktu optimal sangatlah penting. Dengan mengambil anggapan bahwa reaksi dekomposisi berlangsung secara progresif atau seragam pada seluruh partikel.

Berbeda dengan penelitian Penelitian yang dilakukan oleh Aprian Ramadhan P. dan Munawar Ali (2015) mengenai Pengolahan Sampah Plastik Menjadi Minyak dengan kapasitas 2000 gram atau $2 \mathrm{~kg}$. Adapun hasil kenaikan produknya yaitu pada menit ke 10 produk yang dihasilkan $5 \mathrm{ml}$, menit ke 20 sebanyak 6,92 ml, menit ke 30 sebanyak $9,7 \mathrm{ml}$ , menit ke 40 sebanyak $11,26 \mathrm{ml}$, dan menit ke 60 sebanyak $17,24 \mathrm{ml}$.

Waktu kontak sangat berpengaruh terhadap produk minyak yang dihasilkan, semakin lama waktu proses pirolisis berlangsung maka produk yang dihasilkannya (residu padat, tar, dan gas) makin naik. Kenaikan produk yang dihasilkan akan terjadi sampai dengan waktu tak hingga yaitu waktu yang diperlukan sampai hasil padatan residu, tar, dan gas mencapai konstan dan dihitung sejak proses isotermal berlangsung.

Dari tabel 5.1 diketahui terjadi kenaikan jumlah minyak yang dihasilkan yang terjadi pada masing-masing suhu operasi tiap 20 menit. Semakin tinggi suhu dan semakin lama waktu pemanasan hasil minyak yang dihasilkan akan semakin banyak. Hal ini sejalan dengan penelitian yang dilakukan oleh Sumarni, (2008). Variabel yang terbanyak menghasilkan produk cair dengan parameter plastik HDPE terjadi pada suhu $400^{\circ} \mathrm{C}$ dan waktu operasi 60 menit dengan jumlah produk sebesar $453 \mathrm{ml}$.

Faktor faktor yang dapat mempengaruhi proses pirolisis tersebut yaitu suhu, waktu kontak dan pendingin kondensor sangatlah berperan dalam proses. Semakin Lama proses pirolisis semakin banyak pula Minyak yang dihasilkan. 
Jurnal Sulolipu : Media Komunikasi Sivitas Akademika dan Masyarakat

Vol. 18 No 22018

e-issn : 2622-6960, p-issn : 0854-624X

\section{Nilai Kalor Minyak Setelah Proses Pirolisis}

Kalor adalah salah satu bentuk energi yang dapat berpindah dari satu benda ke benda lainnya karena adanya perbedaan suhu. Ketika dua benda yang memiliki perbedaan suhu bertemu maka kalor akan mengalir (berpindah) dari benda yang bersuhu tinggi ke benda yang bersuhu rendah. Nilai kalor minyak yang dihasilkan setelah melalui proses pirolisis yaitu $11761,5049 \mathrm{kalori} / \mathrm{gr}$ dengan menggunakan alat calorimeter. Dapat diketahui bahwa minyak hasil pirolisis dalam penelitian ini mempunyai prospek yang cukup bagus sebagai bahan bakar alternative, dimana nilai kalor dari minyak hasil pirolisis plastik PET 11761,5049 $\mathrm{kkal} / \mathrm{gr}$, menunjukkan nilai yang tidak jauh berbeda dengan minyak-minyak jenis lainnya seperti Minyak tanah 10955,7 kkal/gr, Minyak solar 10861,35 kkal/gr, Minyak diesel 10622,7 $\mathrm{kkal} / \mathrm{gr}$, maupun minyak hasil pirolisis dari plastik jenis lainnya seperti Minyak pirolisis HDPE $10876 \mathrm{kkal} / \mathrm{gr}$, dan Minyak pirolisis LDPE $10885 \mathrm{kkal} / \mathrm{gr}$.

Adanya perbedaan nilai kalor yang dihasilkan pada minyak hasil pirolisis plastik HDPE, LDPE dan PET disebabkan karena beberapa hal yaitu jenis plastik yang diolah, temperatur proses, penggunaan katalis dan jenis katalis yang digunakan.Sebagian besar penelitian dilakukan dengan reaktor tabung atau batch reaktor.

Untuk mengetahui kondensat yang dihasilkan cair atau padat adalah dengancara visual. Cara ini dilakukan dengan melihat warna cairan yang terdapat pada tempat penampung. Jika warna yang dihasilkan gelap atau bahkan kehitaman, maka hasil tersebut berupa kondensat padat. Sedangkan bila hasil memiliki warnakekuningan, maka hasil tersebut adalah kondensat cair. Cara lainnya adalah dengan menumpahkan sedikit kondensat ke air, bila kondensat adalah kondensat padat maka kondensat tersebut langsung mengeras saat bercampur dengan air. Dengan begitu kondensat yang dihasilkan dapat dipisahkan dengan lebih mudah.

Pada penelitian yang dilakukan jenis kondensat yang dihasilkan yaitu kondensat cair. Terbentuknya kondesat cair, menandakan proses pembakaran yang dilakukan tergolong pembakaran sempurna. Sempurna atau tidaknya suatu pembakaran dipengaruhi oleh suhu dalam reactor, bila telah sempurna suhu akan mencapai suhu thermal cracking plastik PET, begitupun dengan sebaliknya.
4. Penurunan sampah dengan Pemanfaatan limbah plastik menjadi Bahan Bakar Minyak (BBM).

Plastik adalah polimer rantai panjang dari atom yangmengikat satu sama lain. Rantai ini membentuk banyak unit molekul berulang, atau "monomer". Istilah plastik mencakup produk polimerisasi sintetik atau semisintetik,namun ada beberapa polimer alami yang termasuk plastik. Plastik terbentuk dari kondensasi dari zat lain untuk meningkatkan performa atau ekonomi Steven,dalam Sari Permata Diah (2014).

Adapun hasil padatan dari hasil pirolisis plastik PET ini berupa serbuk dan padatan keras. Replikasi pertama dan kedua padatan yang dihasilkan berupa serbuk sedangkan replikasi ketiga berupa padatan keras namun tidak merubah pada berat massanya. Hal ini disebabkan karena pada saat percobaan pertama dan kedua ketika percobaan telah selesai padatan tersebut langsung diangkat sehingga adanya kontak langsung antara padatan dengan oksigen berbeda dengan percobaan ketiga setelah selesai perobaan padatan didiamkan dalam reaktor selama sehari dan tidak terjadi kontak secara langsung antara padatan dengan oksigen .

Dari tabel 5.2, diperoleh penurunan massa plastik pada masing-masing suhu operasi tiap 20 menit. Hal ini disebabkan oleh pengaruh suhu dengan waktu kontak. Bertambah tingginya suhu pemanasan maka zat-zat yang terkandung dalam plastik akan terurai menjadi rantai pendek. Peruraian senyawa - senyawa plastik menyebabkan terjadinya penurunan massa plastik yang ada di dalam reaktor.

Zat-zat yang terkandung di dalam plastik PET akan terurai menjadi gas dan cair (minyak). Penurunan massa plastik pada suhu optimum $270^{\circ} \mathrm{C}$ sebelum menit ke 20 padatan belum mengalami penurun yang seknifikan hal ini disebabkan karena proses pembakaran yang terjadi masih belum sempurna. Sedangkan pada menit setelah 60 massa plastik yang tersisa dalam reaktor semakin kecil yaitu $30 \%$. Dengan demikian semakin lama waktu proses pembakaran terjadi maka massa plastik yang ada akan semakin turun. Hal ini menandakan bahwa pada proses pirolisis setiap 20 menit terjadi pengurangan massa pada rantai panjang hidrokarbon.

Penelitian ini sejalan dengan penelitian yang dilakukan oleh aprian ramadhan $p$. dan 
munawar ali (2015) yaitu "pengolahan sampah plastik menjadi minyakmenggunakan proses pirolisis" Penurunan massa terendah terjadi pada suhu $250^{\circ} \mathrm{C}$ dengan waktu operasi $0-60$ menit, massa plastik yang masih ada dalam reaktor sebesar 491,4-413,8 gr. Nilai penurunan massa tertinggi terjadi padasuhu $420^{\circ} \mathrm{C}$ dengan nilai 102,8 gr pada waktu operasi 60 menit.

Pada proses pirolisis, menjaga suhu konstan merupakan faktor terpenting oleh karena itu suhu perlu diperhatikan. Pengaturan suhu dilakukan dari ruang pembakaran, jika suhu dalam ruang pembakaran terlalu tinggi maka blower ditutup agar suhu turun. Jika suhu dalam ruang pembakaran tetap turun meskipun blower sudah dibuka maka bahan bakar ditambahkan ke dalam ruang pembakaran. Akan tetapi penambahan bahan bakar ini tidak diikuti dengan hasil yang baik juga, hal ini dikarenakan masih banyak bahan bakar yang belum terbakar habis.

Berdasarkan uji kinerja yang telah dilakukan, rendemen dari kondensat pirolisis plastik Polypropylene Terephtalate (PET) pada percobaan adalah $70 \%$ penurunan sisa padatan. Hasil rendemen ini lebih besar dari penelitian yang dilakukan oleh aprian Ramadhan dan Ali (2015) dimana rendemen yang dihasilkan adalah $63 \%$. Nilai dari rendemen ini masih dapat ditingkatkan dengan pengaturan suhu yang lebih baik.

Adapun sisa padatan hasil pirolisis tersebut dapat digunakan ulang sebagai bahan campuran untuk aspal hal ini dibuktikan dengan penelitian Apriyadi Dwi Widodo, dkk (2017) yaitu "pengaruh penambahan limbah botol plastik polypthylene terepthalate (PET) dalam campuran laston-wc terhadap parameter marshall". Berdasarkan hasil penelitian yang dilakukan diperoleh beberapa kesimpulan yaitu campuran PET ini dapat digunakan pada kelas jalan kolektor penggunaan campuran PET lebih ekonomis, dibandingkan tanpa campuran PET, campuaran PET juga akan meningkatkan kualitas aspal. Dan pengolahan PET perlu dilakukan cara yang tepat dan hati- hati karena kandungan PET yang dapat menjadi racun berbahaya.

Selain dijadikan sebagai bahan campuran aspal sisa padatan plastik jenis plastik polypthylene terepthalate (PET) juga dapat diolah menjadi paraffin bahan baku untuk pembuatan lilin, namun hal ini butuh proses lebih lanjut untuk mengolah sisa padatan tersebut. Alat Pengolah limbah sampah plastik sangat sesuai untuk digunakan dalam mengatasi masalah polusi lingkungan akibat sampah plastik yang sulit terurai. Seperti yang diketahui sampah plastik merupakan masalah yang sangat serius untuk ditanggulangi. Saat ini penanggulangan sampah plastik belum terlihat jelas, sampah plastik di bakar masih menjadi solusi yang sering dilakukan guna meminimalisir volume sampah. Jika penanggulangan sampah plastik hanya dengan pembakaran maka akan berdampak pada lingkungan sekitar, karena dapat mencemari lingkungan dan berdampak pada mahluk hidup disekelilingnya dikarenakan hasil pembakaran plastik menghasilkan gas dioksin yang bersifat karsinogen yang dapat menyebabkan gejala timbulnya kanker. Efek samping dioksin terhadap binatang adalah perubahan sistim hormon, perubahan pertumbuhan janin, menurunkan kapasitas reproduksi, dan penekanan terhadap sistim kekebalan tubuh. Efek samping dioksin terhadap manusia yaitu perubahan kode keturunan.

Selain dapat menimalisir volume sampah mesin ini juga mampu menghasilkan bahan bakar alternatif guna mengatasi kelangkaan bahan minyak yang semakin meningkat. Alat ini bisa diproduksi massal dan digunakan ditempat pembuangan akhir sampah untuk mengatasi polusi lingkungan akibat sampah plastik yang ada di Indonesia.

Berdasarkan data Jambeck (2015), Indonesia berada di peringkat kedua dunia penghasil sampah plastik ke laut yang mencapai sebesar 187,2 juta ton setelah Cina yang mencapai 262,9 juta ton. Berada di urutan ketiga adalah Filipina yang menghasilkan sampah plastik ke laut mencapai 83,4 juta ton, diikuti Vietnam yang mencapai 55,9 juta ton, dan Sri Lanka yang mencapai 14,6 juta ton pertahun. Setiap tahun produksi plastik menghasilkan sekitar delapan persen hasil produksi minyak dunia atau sekitar 12 juta barel minyak atau setara 14 juta pohon. Lebih dari satu juta kantong plastik digunakan setiap menitnya, dan 50 persen dari kantong plastik tersebut dipakai hanya sekali lalu langsung dibuang. Dari angka tersebut, hanya lima persen yang benar-benar di daur ulang. Wega, (2017). Berdasarkan asumsi Kementerian Lingkungan Hidup (KLH) setiap hari penduduk Indonesia menghasilkan $0,8 \mathrm{~kg}$ sampah per orang atau secara total sebanyak 189 ribu ton sampah/hari. Dari jumlah tersebut $15 \%$ berupa sampah plastik atau sejumlah 28,4 ribu ton 
sampah plastik/hari Sumarni,(2008). Untuk menghasilkan 1 liter minyak BBM dengan hasil penelitian 201,67 ml membutuhkan waktu selama 4,5 jam dengan biaya perjamnya 1.304,- dan efisisensi secara ekonomis dengan membandingkan harga bensin 7000 jadi efisiensi bisa berkurang 1.132,--

\section{PENUTUP}

\section{KESIMPULAN}

a. Alat pirolisator berupa pengolah limbah sampah plastik menjadi bahan bakar alternatif dengan menggunakan prinsip pirolisis mampu menghasilkan bahan bakar minyak (BBM).

b. Metode pirolisis yang digunakan dalam penelitian ini mampu menghasilkan cairan minyak sebanyak $36,67 \mathrm{ml}$ pada menit ke 20, adapun cairan minyak yang dihasilkan pada menit ke 40 sebanyak 114,80 ml dengan, sedangkan dimenit ke 60 sebanyak 201,67 ml. c. Pemanfaatan $1 \mathrm{~kg}$ limbah plastik menjadi bahan bakar minyak (BBM) dapat menurunkan padatan sampah plastik sebanyak $0,7 \mathrm{~kg}$ atau $70 \%$.

\section{Saran}

Setelah melakukan penelitian, maka saran yang diberikan untuk penelitian selanjutnya adalah :

a. Perlu dipasangi penangkap tar untuk mencegah terjadinya peledakan pada alat

b. Perlu dilakukan penelitian lanjutan tentang pengaruh suhu terhadap proses pirolisis plastik khususnya untuk jenis plastik Polypropylene Terephtalate (PET)

c. Perlu dilakukan penelitian lanjutan untuk mengetahui jenis fraksi pada minyak hasil pirolisis tersebut dengan ketelitian senyawa - senyawa yang terkandung.

\section{DAFTAR PUSTAKA}

A Awaluddin. 2008. Production of Biodesel from A used friying oil And using Hetero geneus Catalyst $\mathrm{CaO}$. Jogjakarta: Gadjah Mada University Press.

Alex, S. 2012. Sukses Mengolah Sampah Organik Menjadi Pupuk Organik. Yogyakarta: Pustaka Baru Press Sleman

Anonim, 2017. Sampah. Wikipedia. https://id.wikipedia.org/wiki/Sampah. Diakses Pada Tanggal 9 Januari 2018

Aprian Ramadhan P.\& Munawar Ali. 2015. Pengolahan Sampah Plastik Menjadi Minyak Menggunakan Proses Pirolisis. Jawa Timur: Universitas Pembangunan Nasional. Jurnal.4 (1). http://eprints .upnjatim.ac.id/. Diakses Pada Tanggal 17 Desember 2018

Apriadi Dwi Widodo. 2017. Pengaruh Penambahan Limbah Botol Plastik Polypthylene Terepthalate (Pet) Dalam Campuran Laston-Wc Terhadap Parameter Marshall. Yogyakarta: Jurusan Teknik Sipil.(Online).http://tekniksipil.umy.ac.id/wpcontent/uploads/2014/07/jurnal-PKM-P-PET.pdf. Diakses Pada Tanggal 9 Januari 2018

BPS. 2016. Komposisi Sampah di Makassar. Makassar: Badan Pusat Statistik.

Budi Untoro. 2013. Berbagai metode konversi sampah plastik menjadi bahan bakar minyak. Yogyakarta: Jurusan Teknik Mesin Universitas Janabadra. Jurnal.3 (1). www.jurnalteknik.janabad ra.ac.id/. Diakses Pada Tanggal 4 April 2018.

Chaos Oblong. 2014. Pengolahan Sampah Plastik Menjadi Bahan Pembuatan Lilin. http://boekoebiroe.blogspot.com/2014/05/

bahan.html.Diakses Pada Tanggal 01 Juni 2018 pengolahansampah-plastik-sebagai- 
Jurnal Sulolipu : Media Komunikasi Sivitas Akademika dan Masyarakat

Vol. 18 No 22018

e-issn : 2622-6960, p-issn : 0854-624X

Davidson A., 1970. Hand Book of Precision Engineering. USA: Mc. Graw Hill Book Co. http://books.google.co.id//. Diakses Pada Tanggal 17 Desember 2017.

Fatimah 2004, Pengaruh laju Pemanasan Komposisi Biofuel Hasil Pirolisis Serbuk Kayu. Yogyakarta: Universitas Ahmad Dahlan. Jurnal.1 (1) http://repository.upnyk.ac.id/564/1/24.pdf. Diakses Pada Tanggal 4 April 2018.

Jambeck and Jenna R. 2015. Plastic Waste Inputs From Land Into The Ocean. Jurnal.347.6223 : 768771. https://wedocs.unep.org/bit stream/handle/20.500.11822/17969/Plastic_waste_inputs_from_land_into_the_ocean.pdf? sequence $=1$ \&isAllowed $=y$. Diakses Pada Tanggal 4 Januari 2018.

Kadir, 2012, Kajian Pemanfaatan Sampah Plastik Sebagai Sumber Bahan Bakar Cair, 3.2: 223-228

Malcolm, Steven dkk. 2001. Kimia Polimer. Yogyakarta: Universitas Gadjah Mada.

Mohana Jeya Valli, G.Gnanavel, Dkk. 2012. Alternate Fuel From Synthetic. Pengolahan Limbah Plastik Menjadi Bahan Bakar Alternatif Dengan Metode Destilasi. Skripsi. Banjar Baru: Jurusan Teknik Mesin Universitas Lambung Mangkurat. (Online). http://scholar.tmnulm.ac.id/. Diakses Pada Tanggal 17 Desember 2017

Munawar, dkk. 2012. Pengolahan Sampah Plastik Menjadi Minyak Menggunakan Proses Pirolisis. Jawa Timur: Prodi Teknik Lingkungan, Fakultas Teknik Sipil dan Perencanaan Universitas Pembangunan Nasional. Jurnal.4 (1) : (Online).http://eprints.upnjatim.ac.id/4247/1/(6)Jurnal_Munawa ar.pdf. Diakses Pada Tanggal 17 Desember 2017

Sukmatama. 2013. Mengolah limbah plastik menjadi energi. Jakarta: PT. Artha Teknindo.

Sari Diah Permata. 2014 Pembuatan Plastik Biodegerabble Menggunakan Pati dari Kedelai. Skripsi. Palembang: Politeknik Negeri $\quad$ Sriwijaya. http://repository.uinjkt.ac.id/dspace/bitstr/. Diakses Pada Tanggal 16 Desember 2017.

Sucipto dan Cecep Dani. 2012. Teknologi Pengolahan Daur Ulang Sampah. Pontianak: Gosyen Publishing. http://books.google. co.id//. Diakses Pada Tanggal 16 Desember 2017.

Sumarni. 2008. Kinetika Reaksi Pirolisis Plastik Low Density Poliethylene (LDPE). Yogyakarta: Jurusan Teknik Kimia,Institut Sains dan Teknologi.

Surono, dkk. 2016. Pengolahan Sampah Plastik Jenis PP, PET dan PE Menjadi Bahan Bakar Minyak dan Karakteristiknya. Yogyakarta: Fakultas Teknik, Universitas Janabadra. Jurnal.1 (1) : 32-37. (Online). http://e-journal.janabadra.ac.id/index.php/ JMST. Diakses Pada tanggal 17 Desember 2017

Sodikin Mandala Putra. 2011. Teknologi Pemanfaatan Batubara Untuk Menghasilkan Batubara Cair, Pembangkit Tenaga Listrik, Gas Metana Dan Briket Batubara. Palembang: Jurusan Teknik Pertambanngan Universitas Sriwijaya. (Online). http://eprints.unsri.ac.id/138/1/Pages_ from_PROSIDING_AVOER_2011-32.pdf. Di Akses Pada Tanggal 9 Januari 2018

Wega, Trisunaryanti. 2012. Dari Sampah Plastik Menjadi Bensin dan Solar. Yogyakarta: Gadjah Mada University Press.

Wied, Hary Apriaji. 2004. Memproses Sampah. Jakarta : Penebar Swadaya. http://books.google.co.id//. Diakses Pada Tanggal 4 April 2018 